\title{
Sosyal Harcama Türleri ve Ekonomik Büyüme İlişkisi: Türkiye Örneği
}

\section{Social Expenditure Types and Economic Growth Nexus: The Case of Turkey}

\author{
Musa ÖZTÜRK* \\ (iD) 0000-0002-0902-5787
}

Sosyal Güvenlik Dergisi / Journal of Social Security

Cilt: 10 Say1: 1 Y1l: 2020 /Volume: 10 Issue: 1 Year: 2020 Sayfa Aralığı: 107-124 Pages: 107-124

DOI: $10.32331 /$ sgd.753037

\section{ÖZ}

Refah devleti yaklaşımının yerini küreselleşme söylemi altında neoliberal politikalara bırakmasıyla birlikte, iktisadi işleyişe dâhil olamayan ve/veya çarpık bozuk çarkların altında ezilenlerin mağduriyetini gidermek üzere sosyal harcamaların boyutu ve mahiyeti önem kazanmaya başlamıştır. Bu doğrultuda ülkeler bir taraftan ekonomik büyümenin kapsayıcı ve sürdürülebilir olması diğer taraftan da insan hakları ve demokrasi gibi kavramlar altında sıralanan değerler/çıkarlar nedeniyle sosyal harcamalara ayırdıkları payı arttırma yoluna başvurmuşlardır. Sosyal harcamalardaki bu artış, teorik anlamda bunların ekonomik işleyişe katkıda bulunabileceğini iddia eden Keynesgil görüş ile bunları kaynak kullanım etkinsizliği olarak tanımlayan Neoliberal yaklaşım arasında tartışmaları beraberinde getirmiştir. Konuyla ilgili yapılan uygulamalı çalıșmaların farklı sonuçlar ortaya koyuyor olması, sosyal harcamaların mahiyeti ve boyutunun detaylı bir şekilde ele alınması ihtiyacını ortaya koymaktadır. Bu çalışma kapsamında sosyal harcama türleri ile ekonomik büyüme arasındaki ilişki, Türkiye özelinde, eşbütünleşme ve nedensellik testleriyle incelenmektedir. Analiz sonuçlarına göre uzun dönemde GSYH ile toplam sosyal harcamalar, yaşlılar, kazazede-maluller, engelliler ve sağlık kapsamındaki harcamalar -yapısal kırılmalarla- birlikte ilişkilidir. Nedensellik testleri sonuçlarına göre 'diğer sosyal politika alanları' kapsamı dışındaki sosyal harcamalar dışındaki sosyal harcama türlerinin ekonomik büyümeye neden olduğu tespit edilmiştir. Sonuçlar bir arada değerlendirildiğinde; sosyal harcamaların ekonominin genel işleyişi bakımından faydalı olduğunu ifade eden Keynesgil yaklaşımın Türkiye için genel olarak geçerli olduğu ve neoliberal önermelerin sadece 'diğer sosyal politika alanları' kapsamında yapılan harcamalar için geçerli olduğu sonucuna ulaşılmıştır.

Anahtar Sözcükler: Sosyal harcama türleri, ekonomik büyüme, hatemi-j eşbütünleşme testi

\section{ABSTRACT}

As the welfare state approach was replaced by neoliberal policies, which are implemented under the discourse of globalization, the size and nature of social expenditures began to gain importance, in order to support people who could not participate in the economic process. In this respect, countries have tried to increase their share in social expenditures due to make economy inclusive and sustainable. This increase in social expenditures has led to discussions between the Keynesian view, which argues that they can contribute to economic functioning, and the Neoliberal approach, which defines them as resource use inefficiency or waste. Studies on this subject, which is theoretically controversial, reveal various results. This triggers the need to consider the nature of social expenditures in detail. In the scope of this research, the relationship between types of social spending and economic growth are analyzed with cointegration and causality tests for Turkey. According to the results of the analysis, there is a long-term relationship -with structural breaks- between GDP and total social expenditures, expenditures for the old age, survivors, incapacity related and health. According to the results of causality tests; It has been determined that all types of social expenditures except 'other social policy areas' cause economic growth. When the results are evaluated together; It is found that social expenditures are beneficial to the overall economy as the Keynesian approach argued and Neoliberal propositions are valid for only expenditures in the scope of 'other social policy areas'.

Keywords: Social expenditure types, economic growth, hatemi-j cointegration test

Önerilen atıf şekli: Öztürk, M. (2020). Sosyal Harcama Türleri ve Ekonomik Büyüme İlişkisi: Türkiye Örneği. Sosyal Güvenlik Dergisi (Journal of Social Security). 10(1). 107-124.

\footnotetext{
* Dr., Şırnak Üniversitesi, İktisadi ve İdari Bilimler Fakültesi, İktisat Bölümü, mozturk@sirnak.edu.tr
} 


\section{GİRIŞ}

Bireyin, sosyoekonomik ve politik işleyiş̧e öne çıktığı son iki asırda yaşanan gelişmeler günümüz dünyasının çok boyutlu olarak ele alınabilmesine olanak sunmaktadır. Özellikle son yarım yüzyılda ulaşım ve iletişim alanında kaydedilen mesafeyle birlikte dünyanın daha da küçülmesi, değişim ve dönüşümlerin daha kısa periyotlarda ve daha yüksek frekanslarda meydana gelmesini sağlamaktadır. Bu durum değişimlere hazır olmayan ve/veya değişme karakteristiğine sahip ol(a)mayan kurumların/kesimlerin sarsılmasına neden olmakta ve çok yönlü krizleri tetiklemektedir. 1980 sonrasında küreselleşme kavramı altında ele alınan bu değişim süreci ekonomi merkezinde incelendiğinde, birey ve toplum arasındaki ilişkiye dair yeni normalin oluştuğu ve bu yeni normalde devletin konumu, boyutu ve fonksiyonunun tartışmaları tetiklediği görülmektedir. Bu süreçte değişimlerin ortaya koyduğu firsatlar göz kamaştırırken madalyonun diğer tarafındaki manzara içler acısı bir hal almakta, yaşanan bunalımlar, krizler, isyanlar, savaşlar vb. gelişmeler dünya genelinde sıkça karşılaşılır hale gelmektedir.

Madalyonun iki yüzündeki manzaralar arasındaki farkın açılması sosyoekonomik ve politik anlamda büyük riskleri barındırmakta ve kaynakların tam ve etkin kullanımı önünde engel teşkil etmektedir. $\mathrm{Bu}$ nedenle aradaki farkın giderilmesine yönelik sosyal hizmetler ve politikalar tarihin ilk dönemlerinden itibaren uygulanmaktadır (Şeker, 2012: 32). Bu uygulamalar son iki yüzyıldır sosyal devlet, sosyal politika ve sosyal adalet kavramları kapsamında ele alınmaktadır. Sosyal devlete olan ihtiyaç, özellikle sanayi devriminin çarkları altında ezilen iş̧̧i sınıfının yaşadığı büyük trajedi ve 1929 Büyük Buhranı ile pekişmiştir. Yaşanan krize piyasayı ve görünmez elin marifetini önemseyen liberal yaklaşımın çözüm üretememesi ekonomiye müdahale edilmesini öngören Keynesgil politikalara ve Refah Devleti yaklaşımına alan açmış, kamusal harcamaları ve dolayısıyla sosyal harcamaları gündeme taşımıştır (Gümüş, 2018: 34). 'Sosyal devletin altın çağı' olarak tanımlanan ve II. Dünya Savaşı'ndan 1970'lere değin süren (Aydın ve Çakmak, 2017: 1) bu süreçte Refah devleti anlayışı yoksulluğu ve toplumsal eşitsizliği azaltmak, eğitim düzeyini geliştirmek, sağlık sistemine erişimi ucuz-ücretsiz hale getirmek gibi taahhütlerle yola çıkmış ve birçok gelişmiş ülkede ciddi oranlarda karşılık bulmuştur. Bununla birlikte sosyal harcamaların etkinliği veya daha açık ifadeyle ekonominin geneli üzerinde etkisinin ne olduğu ne pahasına, nasıl ve ne zaman şekillendiği tartışılmaya başlanmıştır (Malyovanyi vd., 2018: 390).

Refah devleti yaklaşımının cömert uygulamaları, 1971'de Bretton Woods sisteminin yıkılması, 1973-1974'te birinci 1979-1980'de de ikinci petrol şoklarıla eleştirilmeye başlanmıştır. Gelişmeler neticesinde Keynesgil yaklaşımdan neoliberal anlayışa geçiş gündeme gelirken refah devletinin ve dolayısıyla sosyal harcamaların sonunun geldiği veya daha hafif ifadeyle şekil değiştirmesi gerektiği düşüncesi yeşermeye başlamıştır (Gümüş, 2018: 63-64). Devlet paradigmasından piyasa paradigmasına doğru yönelişin olduğu ilk dönemlerde karma refah uygulamaları karşılık bulmaya başlamıştır. Bu durum kamusal sosyal hizmetlerin sivil organizasyonlarla tamamlanmasını beraberinde getirmiş ve sosyal hizmetlerde devletin rolünün ne olacağı ve sınırlarının neye göre belirlenmesi gerektiği konuları tartışılmıştır. 1980'lerde piyasanın başrole geçmesiyle birlikte refah devleti dönemlerinde aşina olunan öngörülebilirlik belirsizliğe, teklik çoğulculuğa ve düzen de düzensizliğe doğru değişim göstermiştir. Bu dönemde bilişim teknolojilerinde yaşanan devrimsel değişimlerle, bilginin hızlı ve katlanarak büyümesi, oluşan yeni normalin dinamik özellikler taşımasını sağlamıştır (Sayılı vd., 2015: 53).

Neoliberal politikalar öncülüğünde şekillenen cari küresel ekosistemde başat role sahip olan ülkelerin hepsinin geçmişinde refah devleti tecrübesi varken (Lindert, 1996: 21) bu ülkelerin -Ha-Joon Chang'ın (2002) ifadesiyle- 'merdiveni tekmelemek' yaklaşımına paralel şekilde 
Sosyal Harcama Türleri ve Ekonomik Büyüme İlişkisi: Türkiye Örneği

refah devleti uygulamalarını değersiz ilan etmeleri ve bunu yaparken de karşı karşıya kaldıkları şoklarını ve kronik hale gelen sorunlarını doğalmış gibi göstermeye odaklandıkları bilinmektedir. Bu durum gelişmekte olan ülkelerin 'en iyi politika - best policy' ve 'en iyi örnek - best practice' arayışında tereddüt yaşamalarına neden olmakta ve zaten kıt olan kaynaklarla sosyal harcamalar konusunda etkin politika setinin nasıl oluşturulacağ 1 tartışmalarını tetiklemektedir. Konunun önemi ve kapsamı düşünüldügünnde Türkiye'nin de dâhil olduğu bu ülkelerdeki sosyoekonomik ve politik tartışmaların açık ve örtülü gündeminin kamu kaynaklarının nasıl dağılacağı olduğu görülebilmektedir. $\mathrm{Bu}$ nedenle sosyal harcama türleri ve bunların etkinliği üzerine yoğunlaşan çalışmalar yaygınlaşmaktadır.

Çalışma kapsamında sosyal harcama türlerinin ekonomik büyümeyle ilişkisi irdelenmektedir. Devam eden bölümde sosyal harcama kalemleri ve bunların ekonomik büyüme üzerindeki etkisine dair teorik çerçeve ve literatür taraması sonuçlarına yer verilmektedir. Ardından analiz yöntemleri ve ampirik bulgulara geçilmekte ve nihayetinde değerlendirme ve sonuç kısmında ele edilen bulgular teorik çerçeve ve ilgili literatür kapsamında ele alınmaktadır.

\section{I- TEORİK ÇERÇEVE VE LITERATÜR TARAMASI}

Ekonomik büyüme ve kalkınma yolunda ülkelerin halihazırda sahip oldukları kaynakları tam ve etkin kullanmaları önemlidir ve bu durum özellikle küreselleşme sürecinde keskinleşen rekabet ortamında daha da hayati hale gelmiştir. Kalkınmışlık düzeyinde görece yeterli aşamaları kaydedememiş olan az gelişmiş ve gelişmekte olan ülkelerin içinde bulundukları durumdan hızla çıkabilmeleri için uygulayabilecekleri politika demeti sınırlıdır ve bu kısıtlılık hali ülkeleri etkin strateji arayışına sevk etmektedir. Ülkeler, ekonomik büyüme ve kalkınma süreçlerini dengeli, kapsayıcı ve sürdürülebilir şekilde yönetebilmek için kıt olan kaynaklarını tam ve etkin kullanmalıdır ve bu nedenle sosyal harcamalarını itinayla seçmek durumundadir.

Refah devleti yaklaşımının 1970'lerde yaşanan gelişmeler sonrasında yerini neoliberal politikalara bırakmasıyla birlikte ekonomik büyüme yolunda sosyal harcamaların konumu tartışmalı hale gelmiştir. Bu noktada Keynesgil görüş ile Neoliberal görüş arasında bir değiştokuş (trade-off) olduğu kabul edilmektedir. Keynesgil görüşe göre kamu harcamaları başlı̆̆ altında yer alan sosyal harcamaların artması toplam talebi arttıracağı ve çarpan etkisinin ortaya çıkmasını sağlayacağı için oldukça önemlidir. Genişlemeci bir maliye politikası şeklinde ele alınabilen sosyal harcamaların ekonomik oyunun gerisinde/dışında kalan zayıf kesimlerinde ekonomik faaliyetlere katılmasını sağlaması sosyal harcamaların önemini arttırmaktadır. Nitekim sosyal harcamalarda ileri olan ülkelerin istihdam ve ekonomik performans konusunda başarılı olduklarına dair örnekler mevcuttur (Gioacchino ve Sabani, 2009: 389). Ancak sosyal harcamalar; esnek olmamasından dolayı yüksek vergiler ve dış borçlarla çevrilir hale gelebilmesi, işgücü piyasasında atalete neden olması ve rekabet edebilirliği düşürmesi, vergi gelirlerinde ve kaynak tahsisinde bozulmayı kolaylaştırması gibi sonuçlarıyla birlikte düşünüldügünde tartışılır hale gelmektedir (Im vd., 2011: 39). Refah devleti merkezindeki önermelerin aksine neoliberal görüş ise toplam harcamaların kaynakların tam ve etkin kullanılmasını engelleyeceği için istenmeyen-öngörülemeyen sonuçların ortaya çıkmasına (Johnny vd., 2018: 266) neden olacağını belirtmekte ve özellikle kaynakların yetersiz olduğu az gelişmiş ve gelişmekte olan ülkeler için bu durumun oldukça hayati olduğunu vurgulamaktadır.

İki paradigmanın kesişim kümesinde yer alan sosyal harcamalar ile ekonomik büyüme ilişkisi tüm dünyada olduğu gibi Türkiye'de de tartışılmaktadır. Bu kapsamdaki çalışmalarda teorik 
ve pratik bir fikir birliğinin olmadığı görülürken (Johnny vd., 2018: 267), sosyal politika ve programların hazırlanması kapsamında, gelişme özelliklerinin daha dikkatli ve kapsamlı bir şekilde ele alınması ihtiyacı görülmektedir (Im vd., 2011: 49). Nitekim, Ağırman ve Yılmaz'ın (2018) belirttiği üzere sosyal harcamaları da içeren kamu harcamalarının ülke ekonomisi üzerindeki etkisi ülkeden ülkeye değişebilmektedir. Şöyle ki, az gelişmiş ülkeler için kamu harcamaları ekonomik büyüme üzerinde olumlu etkide bulunurken, gelişmiş ülkeler için negatif etkilemekte, gelişmekte olan ülkelerde ise değişkenler arasındaki ilişki bulanıklaşmaktadır. Diğer taraftan Yılgör vd. (2018) değişkenler arasındaki ilişkinin zaman boyutunda değişkenlik gösterebildiğini, kısa dönem için de Keynesyen yaklaşımın geçerli olduğunu, uzun dönemde ise Klasik görüşün geçerli hale geldiğini belirtmektedir.

İlgili literatür incelendiğinde, çalışmaların yoğunlukla sosyal harcamaları da içeren kamu harcamalarına odaklandığı görülmektedir. Bu açıdan güncel çalışmalara bakıldığında kamu harcamalarının ekonomik büyümeyi desteklediği sonucu; Türkiye özelinde Şit ve Karadağ'ın (2018) ve Gövdeli’nin (2019), G-7 ülkeleri için Ökde ve Bülbül’ün (2019) ve OECD ülkeleri için de Kamacı ve Kılıç'ın (2019) çalışmalarında tespit edilmektedir. Diler (2016) ise Türkiye için yaptığı uygulamalı çalışmasında değişkenler arasında bir nedensellik ilişkisinin olmadığını ortaya koymaktadır. Alper ve Demiral (2016) ile Altıner (2019) OECD ülkelerini kapsayacak şekilde, Alper (2017) ise Türkiye özelinde; savunma, sağlık ve eğitim harcamaları bileşenlerine ayırarak kamu harcamalarının ekonomik büyüme üzerindeki etkilerini incelemekte ve bu harcamaların ekonomik büyüme üzerinde etkili olduğu sonucuna ulaşmaktadırlar. Destebaşı (2018) ise -sosyal politikayı yönlendirici fonksiyonlarına vurgu yaparak- aynı değişkenler arasındaki ilişkiyi Türkiye'nin kurucu üyesi olduğu Gelişen Sekiz Ülke (D-8) ülkeleri için araştırmış, savunma ve sağlık kapsamındaki kamu harcamalarının ekonomik büyümeyi desteklemesine karşın eğitim kapsamındaki harcamaların bu etkiyi karşılamadığı sonucuna ulaşmaktadır. Gölpek vd. (2019) ile Yağtu ve Sezgin (2019) Türkiye'de kamu harcamalarının alt bileşeni olarak ele aldığı savunma harcamalarının ekonomik büyümeye neden olmadığ 1 belirtmektedirler. Altun vd. (2018) sağlık kapsamındaki kamu harcamalarının ekonomik büyümeye olumlu etkisinin olduğunu ancak eğitim harcamalarının aynı etkiye sahip olmadığını ifade etmektedir. Çalışkan vd. (2017) ve İğdeli (2019) de eğitim başlığı altındaki kamu harcamalarının ekonomik büyümeye neden olmadığını belirtirken, Karış (2019) ise bu tür harcamalardaki etkinsizliğin sadece kısa dönemde geçerli olduğunu ve uzun dönemde ekonomik büyümeyi etkilediğini işaret etmektedir.

Kamu ve sosyal harcamaların ne olduğu, kapsamı ve nasıl hesaplandığı konularındaki belirsizlikler ve yapılan uygulamalı çalışmalardan elde edilen farklı sonuçlar, ilgili alandaki çalışmaların kapsam bakımından sınırlandırılması ve harcama türlerinin daha detaylı bir şekilde yapılması ihtiyacını şekillendirmektedir. Bu noktada Şeker'in (2011: 18) tasnifiyle; Avrupa Birliği tarafından yayınlanan Avrupa Bütünleştirilmiş Sosyal Koruma İstatistikleri Sistemi (ESSPROS), Ekonomik Kalkınma ve İşbirliği Örgütü’nün (OECD) hazırladığı Sosyal Harcamalar Veri Tabanı (SOCX) ve Uluslararası Çalışma Örgütü (ILO) organizasyonunda yayınlanan Sosyal Koruma Harcamaları ve Performans İncelemeleri (SPERS) olmak üzere üç yöntem öne çıkmakta ve analizler bu veri tabanları üzerinden, özellikle de detaylı harcama türleri ve geniş zaman aralığı sunması bakımından SOCX veri tabanı üzerinden yapılmaktadır. SOCX veri tabanında sosyal harcama kalemleri olarak yaşlılara, engellilere yönelik harcamalar, sağlık harcamaları, aile kapsamındaki harcamalar, aktif emek piyasalarına yönelik harcamalar, işsizlik harcamaları, konut harcamaları ve diğer sosyal harcamalar yer almaktadır. Bu geniş kapsama rağmen sosyal harcamalar ile ekonomik büyüme arasındaki ilişkiye dair çalışmalarda bu kalemlerin tamamının ayrı ayrı analize dâhil edildiği -bu çalışma benzeri- bir çalışmalar oldukça nadirdir.

Konuyla ilgili detaylı ve uygulamalı çalışmalardan olan, Ebeling (2016) yapmış olduğu tez çalışmasında ABD ekonomisi için sosyal harcamaların ekonomik büyüme ve yaşam 
standartları üzerindeki etkinliğini araştırmış ve sonuç olarak konut, engelliler, ücretliler ve diğer sosyal harcama türlerinin olumlu etkide bulunduğunu, buna karşın aile, sağlık, işgücü, işsizlik ve ihtiyarlık kapsamındaki harcamaların olumsuz etkileri barındırdığını tespit etmektedir. Daha genel olarak toplam sosyal harcamaların ekonomik büyüme olan katkısı Furceri ve Zdzienicka (2010), Arısoy, Ünlükaplan ve Ergen (2010), Hassan ve Hisham (2014) ve Malyovanyi vd. (2018)'in çalışmalarıyla teyit edilmektedir. Ersin ve Baş (2019) ise Güney Avrupa refah ülkeleri özelinde yaptıkları çalışmalarında değişkenler arasında uzun dönemli eşbütünleşik ilişkinin olduğunu ve ekonomik büyümeden sosyal harcamalara doğru nedensellik ilişkisinin varlığı sonucuna ulaşmaktadırlar. Gumede (2019) Güney Afrika ülkesi için hazırladığı tez çalışmasında sosyal harcamaların eğitim, sağlık, para arzı ve GSYH ile eşbütünleşik hareket ettiğini ve ekonomik büyümeyi sağladığını, gelir dağılımı ve tüketim harcamalarını temel alan iki yaklaşımla tespit etmektedir. Buna karşın Im, Cho ve Porumbescu (2011), Khan ve Bashar (2015) ve Michel (2018) de sonuçların ülkeden ülkeye farklılaşabildiğini ifade ederken, Reis ve Bueno (2019) kamu sosyal harcamalarının ekonomik büyümeyi olumsuz etkilediği sonucuna ulaşmaktadır.

Sosyal harcama türlerini tekil olarak ele alan çalışmalara bakıldığında ihtiyarlık-emeklilik kapsamındaki çalışmaların öne çıktığı görülmektedir. Bloom vd. (2010), Reimat (2012), Nagarajan vd. (2016) ve Maestas vd. (2016)'ın çalışmaları yaşlılık ile ekonomik büyümenin ilişkide olduğunu işaret etmektedir. İlave olarak Rubin vd., (2016) sosyal harcamaların genel sağlık durumu üzerinde etkili olduğunu ve Minoru vd. (2018) işsizlik kapsamındaki sosyal harcamaların sermaye birikimi ve kişi başına düşen gelir düzeyinde artışa neden olacağını ifade etmektedirler. Elekdağ'da (2012) bu sonucu doğrular şekilde işgücü piyasalarına yönelik sosyal harcamaların uzun dönemli büyümeyi sağlayacağını belirtmektedir. Literatür taraması sonuçları sosyal harcamaların çok boyutlu bir kavram olduğunu ispatlar niteliktedir. Baylan'ın (2015) da işaret ettiği üzere kavram; ekonomik büyüme, istihdam, tasarruf, fiyat istikrarı ve gelir dağılımı gibi makroekonomik etkilere sahiptir ve bu etkiler, ülke, zaman dilimi ve harcama türlerine göre değişebilmektedir. Bu girift durum; doğru, tutarlı ve etkin politikalar uygulanabilmesi için detaya inilmesi ihtiyacını beslemektedir.

\section{A- Metodoloji}

Küreselleşme sürecinin hızlandığg ve Türkiye'nin de yapısal dönüşüm yaşadığg 1980 sonrası dönemde sosyal harcama kalemlerinin ekonomik büyümeyle ilişkisi aşağıdaki eşbütünleşme ve nedensellik testleriyle incelenmektedir.

\section{i) Hatemi-J (2008) Eşbütünleşme Testi}

Zaman serileri kapsamında oluşturulan modellere ele alınan değişkenlerin uzun dönemdeki ilişkileri eşbütünleşme testleriyle incelenmektedir. Bu kapsamda geliştirilen öncü testler değişkenler arasındaki ilişkiyi bütüncül ele almışlar ve yapısal değişmelerin olma durumunu dışsal olarak kabul etmişlerdir. Ancak zaman içinde yapılan çalışmaların yapısal kırılmalar altında ilişkilerin anormallik gösterebildiğini ve farklı sonuçlar sunabildiğini göstermesi yapısal kırılmaları içeren eşbütünleşme testlerinin geliştirilmesi ihtiyacını ortaya çıkarmıştır. Yapısal kırılmaları analize dâhil eden ilk eşbütünleşme testi uzun dönemli ilişkide tek yapısal kırılmayı tespit eden Gregory ve Hansen (1996) testidir. Hatemi-J (2008) ise uzun dönemli ilişkide birden fazla yapısal kırılma olması durumunda bu testin açıklama kabiliyetinin sınırlı olacağını ifade ederek, düzeyde ve eğimde olmak üzere çift içsel yapısal kırılma tespit eden ve aşağıdaki modeli temel alan testi geliştirmiştir (Yılancı ve Öztürk, 2010: 267-268).

$$
y_{t}=\alpha_{0}+\sum_{i=1}^{2}\left(\alpha_{i} D_{i t}+\beta_{i}^{\prime} D_{i t} x_{t}\right)+\beta_{0}^{\prime} x_{t}+u_{t}
$$


$\alpha_{0}, \alpha_{1}$ ve $\alpha_{2}$ değişkenleri sırasıyla yapısal kırılma öncesi, birinci yapısal kırılma sonrası ve ikinci yapısal kırılma sonrası sabit terimdeki değişmeleri işaret etmektedir. $\beta_{0}, \beta_{1}$ ve $\beta_{2}$ parametreleri ise sırasıyla yapısal kırılma öncesi, birinciden ve ikinciden sonraki trenddeki yapısal değişmeleri ifade etmektedir. $\tau_{1} \in(0,1)$ ve $\tau_{2} \in(0,1)$ rejim değişimi tarihlerini temsil ederken, gölge değişkenler;

$$
D_{1 t}=\left\{\begin{array}{ll}
1 & \mathrm{t}>\left[n \tau_{1}\right] \\
0 & \mathrm{t} \leq\left[n \tau_{1}\right]
\end{array}\right\} \quad \text { ve } \quad D_{2 t}=\left\{\begin{array}{ll}
1 & \mathrm{t}>\left[n \tau_{2}\right] \\
0 & \mathrm{t} \leq\left[n \tau_{2}\right]
\end{array}\right\}
$$

şeklindedir. Burada değişkenler arasındaki ilişkiye dair temel hipotez $A D F^{*}, Z_{\alpha}$ ve $Z_{t}$

testleriyle sınanır. ADF* modeldeki kalıntılara uygulanan ADF birim kök testiyle elde edilirken, $Z_{\alpha}$ test istatistiği; $Z_{\alpha}=n\left(\hat{p}^{*}-1\right)$ üzerinden ve $\hat{p}^{*}$;

$$
\hat{p}^{*}=\frac{\sum_{t=1}^{n-1}\left(\hat{u}_{t} \hat{u}_{t+1}-\sum_{j=1}^{B} w(j / B)\left(\frac{1}{n} \sum_{t=j+1}^{T}\left(\hat{u}_{t-j}-\hat{p} \hat{u}_{t-j-1}\right)\left(\hat{u}_{t}-\hat{p} \hat{u}_{t-1}\right)\right)\right)}{\sum_{i=1}^{n-1} \hat{u}_{t}^{2}}
$$

olacak şekilde hesaplanmaktadır ve buradan hareketle $Z_{t} \quad \hat{p}^{*}$ üzerinden şöyle bulunabilir;

$$
Z_{t}=\frac{\left(\hat{p}^{*}-1\right)}{\left(\hat{\gamma}(0)+2 \sum_{j=1}^{B} w(j / B) \hat{\gamma}(j)\right) / \sum_{1}^{n-1} \hat{u}_{t}^{2}}
$$

$A D F^{*}, Z_{\alpha}$ ve $Z_{t}$ istatistikleri normal olmayan dağılıma sahiptir ve $\tau_{1}$ ve $\tau_{2}$ için en küçük test istatistikleri kullanılmakta ve Hatemi-J (2008) kritik değerleriyle karşılaştırılarak yapısal kırılmaların anlamlılığı araştırılmaktadır (Hatemi-J, 2008: 499-502; Yılancı ve Öztürk, 2010: 267-268).

\section{ii) Granger Doğrusal Nedensellik Testi}

Değişkenler arasındaki ilişkinin nedensellik merkezinde ele alınması ekonometrik analizde önemli yer tutmaktadır. C. W. J. Granger (1969)'in lokomotifliğini üstlendiği nedensellik analizlerinde Sims (1972), Gweke vd. (1983), Toda-Yamamoto (1995) ve benzeri birçok çalışma yapılagelmiştir (Taşar, 2015: 57). İki değişkenden birindeki değişimin diğeri tarafından açıklanabiliyor olması durumunu ifade eden nedensellik ilişkilerinde (Takım, 2010: 6) analizin yapılabilmesi için serilerin durağan olması ve durağan halde analiz edilmesi gerekmektedir.

$$
Y_{t}=\alpha_{10}+\sum_{i=1}^{L_{11}} \alpha_{11} Y_{t-1}+\sum_{j=1}^{L_{12}} \alpha_{12 j} X_{t-j}+u_{1 t}
$$




$$
\begin{aligned}
& X_{t}=\alpha_{20}+\sum_{i=1}^{L_{21}} \alpha_{21} Y_{t-1}+\sum_{j=1}^{L_{22}} \alpha_{22 j} X_{t-j}+u_{2 t} \\
& H_{0}: \alpha_{12 j}=0 \quad j=1,2,3, \ldots \ldots \ldots, L_{12} \text { için } \\
& H_{1}: \alpha_{12 j} \neq 0 \quad \text { en az bir } j \text { için }
\end{aligned}
$$

$X_{t}$ ve $Y_{t}$ değişkenleri için yukarıda yer alan Granger nedensellik modelinde $u_{1 t}$ ve $u_{2 t}$ hata terimleridir. Nedensellik ilişsileri $\alpha_{12}$ ve $\alpha_{22}$ değişkenlerinin aldıkları değerlerin sıfırdan farklı olmasıyla gösterilmektedir ve ikisi de sıfırdan farklı olduğunda iki yönlü nedensellik ilişkisinin varlığı söz konusudur (Duman, 2017: 21).

\section{iii) Toda-Yamamoto Doğrusal Nedensellik Testi ve Bootstrap Yaklaşımı}

Makroekonomik analizler başta olmak üzere ampirik çalışmalarda yaygın olarak kullanılan Granger (1969) nedensellik testinin hata terimlerinde sapmalı sonuçlar verebiliyor olması, değişkenlerin düzey değerleriyle incelenebildiği ve Wald-değeri ile $\chi^{2}$ dağılımına dayalı olan Toda-Yamamoto (1995) testine kapı aralamıştır. Standart VAR modelinde değişkenlerin aynı dereceden durağan olması gerekirken Toda-Yamamoto testinde bu durum gecikme uzunluğu ve maksimum bütünleşme derecesinin bir arada ele alınmasıyla oluşturulan VAR $\left(k+d_{\max }\right)$ ile tahmin edilir (Taşar, 2015: 58-59).

$$
\begin{aligned}
& \ln X_{t}=\sum_{i=1}^{k+d_{\max }} \alpha_{1 i} \ln X_{t i}+\sum_{i=1}^{k+d_{\max }} \beta_{1 i} \ln Y_{t i}+\varepsilon_{1 t} \\
& \ln Y_{t}=\sum_{i=1}^{k+d_{\max }} \alpha_{2 i} \ln Y_{t i}+\sum_{i=1}^{k+d_{\max }} \beta_{2 i} \ln X_{t i}+\varepsilon_{2 t}
\end{aligned}
$$

Hacker ve Hatemi-J (2005-2006), Toda-Yamamoto testinin düşük gözlem sayısına sahip olan serilerde ARCH etkisinden etkilenişi sorununu gidermek için teste Efron (1979) tarafından geliştirilen bootstrap yaklaşımını ekleyerek;

$$
y_{t}=v+A_{1} y_{t-1}+A_{2} y_{t-2}+\ldots+A_{p} y_{t-p}+A_{p+d_{\max }} y_{t-p-d_{\max }}+\varepsilon_{t}
$$

Denklemine ulaşmışlardır (Hacker ve Hatemi-J, 2006: 1490; Bayat vd. 2012: 124). Kritik değerlerin karşılaştırılacağı MWALD istatistiği aşağıdaki denklem 11 de gösterilmektedir.

$\otimes$ Kronecker Çarpımı, $C$ pxn $\left(1+\left(p+d_{\max }\right)\right)$ matrisi, $S_{U}$ hata terimlerinin kovaryans matrisidir. $\hat{\beta}, Y=D Z+\varepsilon$ şeklindeki $\operatorname{VAR}\left(k+d_{\max }\right)$ modelinde $\operatorname{vec}(D)$ 'yi ifade etmektedir ve vec sütun sınırlayıcı (column-stacking) işlemcisidir (Kayhan vd., 2013: 155).

$$
M W A L D=(C \hat{\beta})^{\prime}\left[C\left(\left(Z^{\prime} Z\right)^{-1} \otimes S_{U}\right) C^{\prime}\right]^{-1}(C \hat{\beta}) \square \chi_{p}^{2}
$$

Bootstrap yaklaşımında MWALD test istatistik değerinin kritik değerlere kıyasla büyük olması durumunda nedensellik ilişkisinin olmadığını ifade eden sıfır hipotezi reddedilir ve alternatif hipotez kabul edilir. 


\section{B- Ampirik Bulgular}

Analizlerde, ilgili literatürde sıkça kullanılan ve en geniş gözlem aralığını kapsayan (19802016) OECD toplam sosyal harcamalar veri tabanı (SOCX) ile IMF veri tabanından (WEO) elde edilen veriler kullanılmaktadır. 2010 yılı sabit fiyatlarıyla Türk Lirasıyla ele alınan sosyal harcama türleri ve kısaltmaları tablo 1 de gösterilmektedir.

Tablo 1. Sosyal Harcama Türleri

\begin{tabular}{ll}
\hline OLD & İhtiyarlık-emeklilik (Old age) \\
\hline INC & Engelliler- iş göremezler (Incapacity related) \\
\hline FAM & Aile (Family) \\
\hline UNE & İşsizlik (Unemployment) \\
\hline OTH & Diğer sosyal politika alanları (Other social policy areas) \\
\hline SUR & Kazazedeler-malüller (Survivors) \\
\hline HEA & Sağlı (Health) \\
\hline ALP & Aktif işgücü piyasası programları (Active labour market programmes) \\
\hline HOU & Konut (Housing) \\
\hline \hline
\end{tabular}

1980 sonrası Türkiye'de sosyal harcamaların gelişimi incelendiğinde, 1980 yılında 7,392 Milyon € olan toplam sosyal harcamaların 2016 yılında 211,755 Milyon €’ye kadar çıkarak yaklaşık 29 kat artış gösterdiği görülmektedir. Bu gelişim sürecinde, Türkiye'de sosyal harcamalar serisinin ekonomik krizlerin yaşandığı 1994, 2000 ve 2001 yıllarında sekteye uğradığı ve 2002 sonrasında yüksek eğimle artış gösterdiği görülmektedir.

Grafik 1. Türkiye'de Toplam Sosyal Harcamalar ile GSYH'nin Gelişimi (1980-2016)

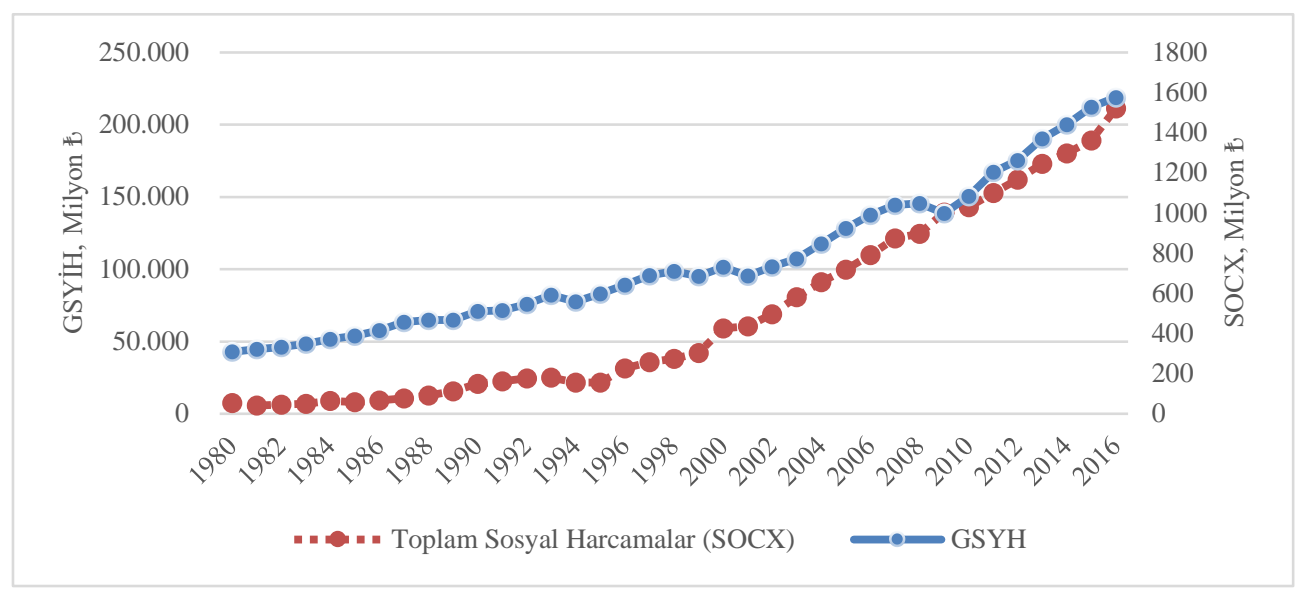

Kaynak: OECD- Sosyal Harcamalar Veri Tabanı

1980 sonrası için GSYH verisindeki gelişmeye bakıldığında ise serinin görece daha yatay eğimde artış gösterdiği ve kriz dönemlerinde (özellikle de 2008 krizinde) sekteye uğradığ ancak sonrasında artışına devam ettiği dikkat çekmektedir.

Grafik 2'de sosyal harcama türlerinden ihtiyarlık-yaşlılık, kazazedeler-malullük, engellileriş görmezler ve sağlık kapsamındaki harcamaların gelişimi gösterilmektedir. Grafikte en üstte ihtiyarlık kapsamındaki sosyal harcamalar yer almaktadır ve bunun 2016 yılı itibariyle toplam sosyal harcamalardaki payı \%50 civarında gerçeklemiştir. Bu durum Türkiye'de emeklilik fonları ve emeklilikte yaşa takılanlar gibi konuların önemi hakkında fikir vermektedir. 
Sosyal Harcama Türleri ve Ekonomik Büyüme İlişkisi: Türkiye Örneği

Grafik 2. Ihtiyarlık, Kazazedeler, İş Görmezlik ve Sağlık Kapsamındaki Sosyal Harcama Türlerinin Gelişimi, (1980-2016)

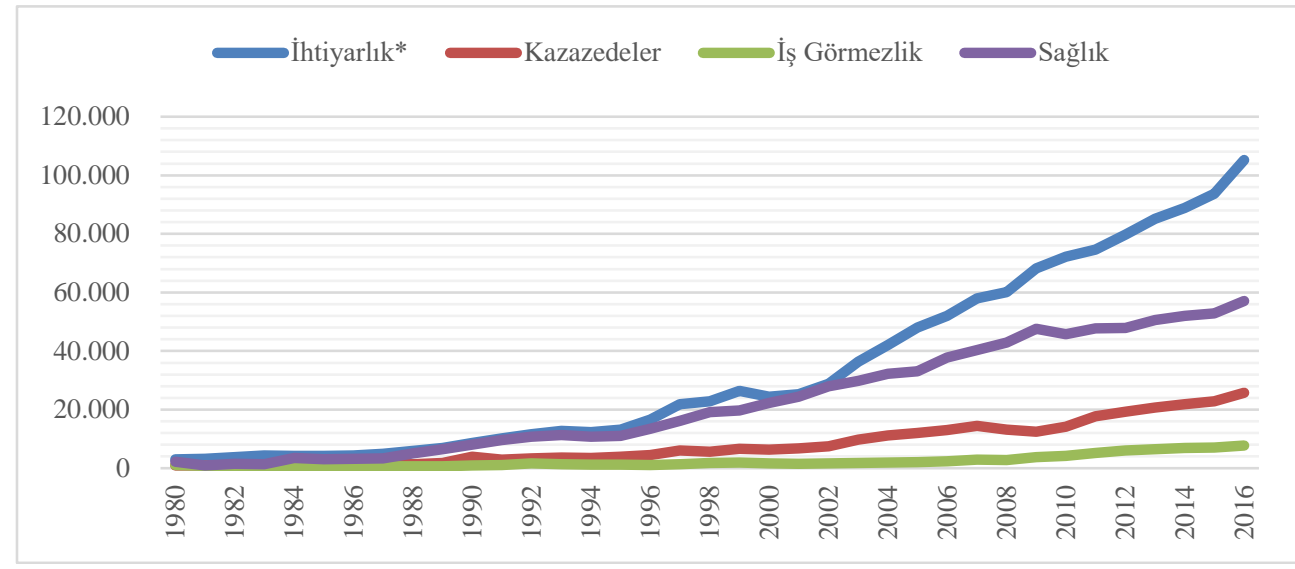

Kaynak: OECD -Sosyal Harcamalar Veri Tabanı. * OECD kaynağındaki eksik İhtiyarlık verileri Knoema'da yer alan verilerden tamamlanmıştır.

İhtiyarlık-emeklilik kapsamındaki sosyal harcamalardan sonra en yüksek pay sağlık harcamalarına ayrılmaktadır. 2016 yılı itibariyle toplam sosyal harcamaların \%30'a yakını bu kapsamda gerçekleşmiştir. Aynı tarihte kazazedeler-malüllere (survivors) toplam harcamaların \%11,8'i, iş görmezler - engellilere (incapacity related) yönelik yapılan sosyal harcamalar ise yaklaşık \%4 düzeyindedir. Konut kapsamındaki sosyal harcamalar ise sadece 5 yılı kapsadığı için grafikte gösterilmemiştir.

Sosyal harcama türlerinden aile, aktif işgücü piyasaları programları, işsizlik ve diğer sosyal politika alanlarındaki harcamalar incelendiğinde, ilk olarak serilerin diğerlerine kıyasla kesikli ve çok daha dalgalı bir seyir izledikleri dikkat çekmektedir. Grafik 3'te en üstte yer alan aile kapsamındaki sosyal harcamalardaki dalgalanma incelendiğinde krizlerin bu grupta yer alan harcamalar üzerinde önemli derecede etkili olduğu görülebilmektedir. 2001 krizi sonrasında ise seriler daha az dalgalı bir şekilde gelişimini sürdürmektedir.

Grafik 3. Aile, Aktif Işsgücü Piyasası Programları, İssizlik ve Diğer Sosyal Politika Harcamalarının Gelişimi, (1980-2016)

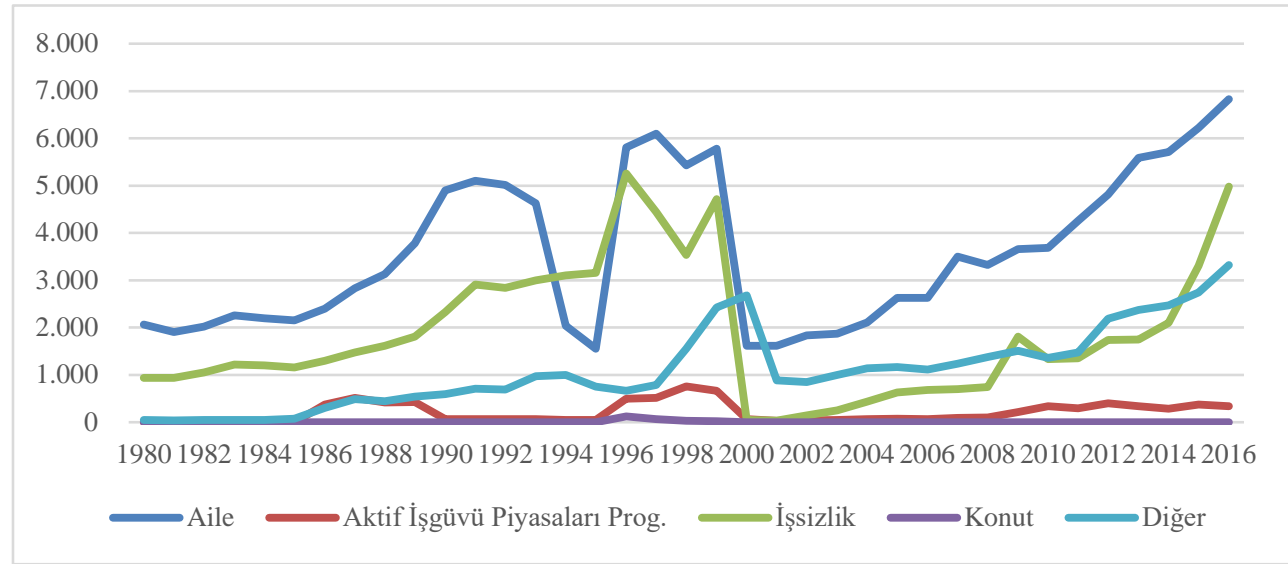

Kaynak: OECD - Sosyal Harcamalar Veri Tabanı 
Aile serisindeki yüksek dalgalanmanın benzeri işsizlik kapsamındaki sosyal harcamalarda görülmektedir. 2000-2001 krizlerinde sıfırlanan seri, sonrasında artışa geçmiş ve 2014 itibariyle büyük gelişim göstermeye başlamıştır. Aktif işgücü piyasaları programı kapsamındaki harcamalar doksanlı yıllardan itibaren düşük seyir izlerken, 2001 yılında sıfırlanan diğer sosyal harcamaların artışa geçtiği görülmektedir.

Analizlerde kullanılan verilere ait istatistiki bilgiler Tablo 2'de sunulmaktadır.

Tablo 2. Tanımlayıcı İstatistikler

\begin{tabular}{lccccccc}
\hline & Ortalama & Medyan & Std. Hata & Çarpıklık & Basıklık & Olasılık & Gözlem \\
\hline GSYH & 761.2132 & 687.958 & 359.98 & 0.74466 & 2.555289 & 0.155329 & 37 \\
\hline SOCX & 68705.45 & 38164.1 & 63728.78 & 0.753451 & 2.179098 & 0.10333 & 37 \\
\hline OLD & 33627.44 & 22909.4 & 31225.45 & 0.80831 & 2.29979 & 0.091403 & 37 \\
\hline SUR & 8254.054 & 6118.9 & 7264.804 & 0.859378 & 2.590954 & 0.090165 & 37 \\
\hline INC & 2368.603 & 1650.1 & 2091.772 & 1.400763 & 3.639975 & 0.00172 & 37 \\
\hline HEA & 23068.66 & 19179 & 18504.38 & 0.402979 & 1.68689 & 0.160442 & 37 \\
\hline FAM & 3593.514 & 3322.7 & 1620.522 & 0.385712 & 1.733416 & 0.183541 & 37 \\
\hline ALP & 207.1757 & 70.9 & 210.9711 & 0.849996 & 2.659605 & 0.098568 & 31 \\
\hline UNE & 1892.838 & 1472.3 & 1417.096 & 0.835227 & 2.833865 & 0.113924 & 37 \\
\hline HOU & 6.751351 & 0 & 23.56671 & 3.956573 & 18.50685 & 0 & 37 \\
\hline OTH & 1111.762 & 969.8 & 861.9829 & 0.807661 & 2.900917 & 0.132804 & 37 \\
\hline
\end{tabular}

- Aktif işgücü piyasası programlarına yapılan harcamalar 1986 yılından itibaren başlamaktadır. Eş bütünleşme ve nedensellik sorgulamaları 31 gözlem üzerinden yapılmaktadır.

- HOU verisi sadece 1996-1999 yılları için mevcut olduğundan sonraki analizlerde yer verilmemektedir.

- GSYH verisi Milyar $€$, diğer veriler Milyon €’dir.

- Eviews 9 programıyla ulaşıllmıştır.

Sosyal harcama türlerinin GSYH üzerindeki etkisi aşağıdaki model üzerinden ayrı ayrı sorgulanmaktadir.

$$
G S Y H=b_{0}+b_{1} X+u_{t}
$$

Modeldeki $X$ yerine sosyal harcama türleri konularak ilişkiler araştırılmaktadır. Bu doğrultuda ilk olarak değişkenlerin durağanlıkları ADF ve PP birim kök testleriyle sınanmıştır.

Tablo 3. Augmented Dickey-Fuller (1979) ve Phillips-Perron (1988) Birim Kök Testleri

\begin{tabular}{|c|c|c|c|c|c|c|c|}
\hline & & Sabit & $\begin{array}{c}\text { Sabit ve } \\
\text { Trend } \\
\end{array}$ & & & Sabit & $\begin{array}{c}\text { Sabit ve } \\
\text { Trend }\end{array}$ \\
\hline & Değişkenler & Olasılık D. & Olasılık D. & & Değişkenler & Olasılık D. & Olasılık D. \\
\hline \multirow{10}{*}{ 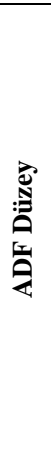 } & GSYH & 1.0000 & 0.9970 & \multirow{10}{*}{ 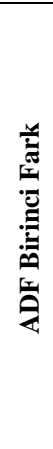 } & $\mathrm{d}(\mathrm{GSYH})$ & $0.0014^{\mathrm{a}}$ & $0.0006^{\mathrm{a}}$ \\
\hline & SOCX & 1.0000 & 0.9894 & & $\mathrm{~d}(\mathrm{SOCX})$ & 0.9023 & $0.0000^{\mathrm{a}}$ \\
\hline & OLD & 1.0000 & 0.9975 & & $\mathrm{~d}(\mathrm{OLD})$ & 0.1771 & $0.0032^{\mathrm{a}}$ \\
\hline & SUR & 1.0000 & 0.9894 & & $\mathrm{~d}(\mathrm{SUR})$ & $0.0029^{a}$ & $0.0008^{\mathrm{a}}$ \\
\hline & INC & 1.0000 & 0.9979 & & $\mathrm{~d}(\mathrm{INC})$ & $0.0123^{b}$ & $0.0017^{\mathrm{a}}$ \\
\hline & HEA & 0.9998 & 0.3551 & & $\mathrm{~d}(\mathrm{HEA})$ & $0.0000^{\mathrm{a}}$ & $0.0000^{\mathrm{a}}$ \\
\hline & FAM & 0.3215 & 0.4298 & & $\mathrm{~d}(\mathrm{FAM})$ & $0.0001^{\mathrm{a}}$ & $0.0004^{\mathrm{a}}$ \\
\hline & ALP & 0.1077 & 0.2896 & & $\mathrm{~d}(\mathrm{ALP})$ & $0.0001^{\mathrm{a}}$ & $0.0010^{\mathrm{a}}$ \\
\hline & UNE & 0.4158 & 0.7386 & & $\mathrm{~d}(\mathrm{UNE})$ & $0.0000^{\mathrm{a}}$ & $0.0000^{\mathrm{a}}$ \\
\hline & $\mathrm{OTH}$ & 0.8816 & 0.1058 & & $\mathrm{~d}(\mathrm{OTH})$ & $0.0002^{\mathrm{a}}$ & $0.0010^{\mathrm{a}}$ \\
\hline
\end{tabular}


Sosyal Harcama Türleri ve Ekonomik Büyüme İlişkisi: Türkiye Örneği

Tablo 3. Augmented Dickey-Fuller (1979) ve Phillips-Perron (1988) Birim Kök Testleri (Devamı)

\begin{tabular}{|c|c|c|c|c|c|c|c|}
\hline & & Sabit & $\begin{array}{c}\text { Sabit ve } \\
\text { Trend }\end{array}$ & & & Sabit & $\begin{array}{c}\text { Sabit ve } \\
\text { Trend }\end{array}$ \\
\hline & Değişkenler & Olasılık D. & Olasılık D. & & Değişkenler & Olasılık D. & Olasılık D. \\
\hline \multirow{10}{*}{ 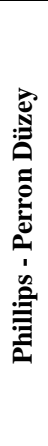 } & GSYH & 1.0000 & 0.9988 & \multirow{10}{*}{ 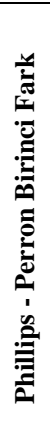 } & d(GSYH) & $0.0013^{\mathrm{a}}$ & $0.0006^{\mathrm{a}}$ \\
\hline & SOCX & 1.0000 & 0.9921 & & $\mathrm{~d}(\mathrm{SOCX})$ & $0.0272^{b}$ & $0.0000^{\mathrm{a}}$ \\
\hline & OLD & 1.0000 & 0.9997 & & $\mathrm{~d}(\mathrm{OLD})$ & 0.2718 & $0.0095^{\mathrm{a}}$ \\
\hline & SUR & 1.0000 & 1.0000 & & d(SUR) & $0.0031^{\mathrm{a}}$ & $0.0000^{\mathrm{a}}$ \\
\hline & INC & 1.0000 & 0.9972 & & $\mathrm{~d}(\mathrm{INC})$ & $0.0125^{b}$ & $0.0017^{\mathrm{a}}$ \\
\hline & HEA & 0.9998 & 0.3399 & & d(HEA) & $0.0000^{\mathrm{a}}$ & $0.0000^{\mathrm{a}}$ \\
\hline & FAM & 0.3215 & 0.4298 & & $\mathrm{~d}(\mathrm{FAM})$ & $0.0000^{\mathrm{a}}$ & $0.0002^{\mathrm{a}}$ \\
\hline & ALP & 0.0771 & 0.2185 & & $\mathrm{~d}(\mathrm{ALP})$ & $0.0001^{\mathrm{a}}$ & $0.0010^{\mathrm{a}}$ \\
\hline & UNE & 0.3338 & 0.6497 & & $\mathrm{~d}(\mathrm{UNE})$ & $0.0000^{\mathrm{a}}$ & $0.0000^{\mathrm{a}}$ \\
\hline & OTH & 0.9828 & 0.5420 & & $\mathrm{~d}(\mathrm{OTH})$ & $0.0000^{\mathrm{a}}$ & $0.0000^{\mathrm{a}}$ \\
\hline
\end{tabular}

- a ve ${ }^{\mathrm{b}}$ işaretleri sırasıyla $\% 1$ ve $\% 5$ anlam düzeylerini işaret etmektedir.

- $t$ istatistikleri MacKinnon (1996) kritik değerleriyle karşıllaştırılmıştır.

- Gecikme uzunluğu Schwarz kriterlerine göre belirlenmiştir.

- Eviews 9 programı kullanılmıştır.

Birim kök sınaması sonuçlarına göre serilerin tamamı birinci fark I (1) durağandır. Serilerin fark halleriyle VAR modeli oluşturulmakta ve böylece nedensellik ilişkilerinde kullanılacak olan gecikme uzunluğu (lag length) tespit edilmektedir. Diğer taraftan değişkenler arasında uzun dönemli ilişkinin olup olmadığı eşbütünleşme testiyle sorgulanmıştır.

Hatemi-J (2008) eşbütünleşme testi sonuçlarına göre GSYH ile uzun dönemli anlamlı eş bütünleşik ilişki SOCX, OLD, SUR, INC ve HEA kapsamındaki harcamalar arasında mevcuttur. Diğer harcama türleriyle uzun dönemli eş bütünleşik ilişki tespit edilememiştir.

Hatemi-J Eşbütünleşme testi sonuçlarına göre değişkenler arasındaki ilişkilerde 1997 ve 2004 yılları yapısal kırılmalar olarak öne çıkmaktadır. Bu tarihlerden ilki, başta emekliler olmak üzere büyük çaplı düzenlemenin yapıldığı tarihe denk gelirken, ikincisi Sosyal Yardımlaşma ve Dayanışma Genel Müdürlüğü'nün kurulduğu tarihe karşılık gelmektedir. GSYH-SUR ilişkisinde seçimlerin ve terör olaylarının gündemi sardığı 1989 ve 1993 yılları yapısal kırılma tarihleri olarak öne çıkarken, GSYH-INC ilişkisinde yapısal kırılmalar kapsamlı ve oldukça tartışmalı sosyal güvenlik reformlarının gündem olduğu 1991 ile büyük Marmara depreminin yaşandığı 1999 yıllarını işaret etmektedir.

Tablo 4. Hatemi-J (2008) Çift Yapısal Kırılmalı Eşbütünleşme Testi Sonuçları

\begin{tabular}{|c|c|c|c|c|c|c|}
\hline & & YK1 & YK2 & Test İstatistiği & AR Lag & İlişski \\
\hline & $\mathrm{ADF}^{*}$ & 1997 & 2004 & $-6.015^{b}$ & \multirow{3}{*}{3} & $\checkmark$ \\
\hline \multirow[t]{3}{*}{ SOCX } & $\mathrm{Zt}$ & 1999 & 2001 & -5.301 & & $x$ \\
\hline & $\mathrm{Za}$ & 1999 & 2001 & -32.397 & & $x$ \\
\hline & $\mathrm{ADF}^{*}$ & 1997 & 2004 & $-5.899^{c}$ & \multirow{3}{*}{3} & $\checkmark$ \\
\hline \multirow[t]{3}{*}{ OLD } & $\mathrm{Zt}$ & 1999 & 2001 & -4.587 & & $x$ \\
\hline & $\mathrm{Za}$ & 1999 & 2001 & -27.271 & & $x$ \\
\hline & $\mathrm{ADF}^{*}$ & 1989 & 1993 & $-6.067^{b}$ & \multirow{3}{*}{0} & $\checkmark$ \\
\hline \multirow[t]{2}{*}{ SUR } & $\mathrm{Zt}$ & 1989 & 1993 & $-6.153^{b}$ & & $\checkmark$ \\
\hline & $\mathrm{Za}$ & 1989 & 1993 & -37.976 & & $x$ \\
\hline
\end{tabular}


Tablo 4. Hatemi-J (2008) Çift Yapısal Kırılmalı Eşbütünleşme Testi Sonuçları (Devamı)

\begin{tabular}{|c|c|c|c|c|c|c|}
\hline & & YK1 & YK2 & Test İstatistiği & AR Lag & İlişski \\
\hline & $\mathrm{ADF}^{*}$ & 1991 & 1999 & $-5.862^{c}$ & \multirow{3}{*}{5} & $\checkmark$ \\
\hline \multirow[t]{3}{*}{ INC } & $\mathrm{Zt}$ & 1990 & 2003 & -4.220 & & $x$ \\
\hline & $\mathrm{Za}$ & 1990 & 2003 & -24.727 & & $x$ \\
\hline & $\mathrm{ADF}^{*}$ & 1997 & 2004 & $-6.845^{a}$ & \multirow{3}{*}{3} & $\checkmark$ \\
\hline \multirow[t]{3}{*}{ HEA } & $\mathrm{Zt}$ & 1999 & 2004 & -3.658 & & $x$ \\
\hline & $\mathrm{Za}$ & 1999 & 2004 & -21.898 & & $x$ \\
\hline & $\mathrm{ADF}^{*}$ & 2003 & 2004 & -5.077 & \multirow{3}{*}{3} & $x$ \\
\hline \multirow[t]{3}{*}{ FAM } & $\mathrm{Zt}$ & 1987 & 1990 & -4.274 & & $x$ \\
\hline & $\mathrm{Za}$ & 1987 & 1990 & -24.518 & & $x$ \\
\hline & $\mathrm{ADF}^{*}$ & 2004 & 2006 & -5.057 & \multirow{3}{*}{0} & $x$ \\
\hline \multirow[t]{3}{*}{ ALP } & $\mathrm{Zt}$ & 2004 & 2006 & -5.143 & & $x$ \\
\hline & $\mathrm{Za}$ & 2004 & 2006 & -31.682 & & $x$ \\
\hline & $\mathrm{ADF}^{*}$ & 2003 & 2004 & -4.897 & \multirow{3}{*}{3} & $x$ \\
\hline \multirow[t]{3}{*}{ UNE } & $\mathrm{Zt}$ & 1986 & 1986 & -4.341 & & $x$ \\
\hline & $\mathrm{Za}$ & 2003 & 2004 & -24.667 & & $x$ \\
\hline & $\mathrm{ADF}^{*}$ & 1993 & 2004 & -4.452 & \multirow{3}{*}{3} & $x$ \\
\hline \multirow[t]{2}{*}{ OTH } & $\mathrm{Zt}$ & 1989 & 1991 & -3.807 & & $x$ \\
\hline & $\mathrm{Za}$ & 2003 & 2004 & -23.189 & & $x$ \\
\hline \multicolumn{7}{|c|}{$\begin{array}{l}\text { - YK1 ve YK2 tanımlamaları sırasıyla birinci ve ikinci yapısal kırılma tarihlerini vermektedir. } \\
\text { - Test istatistikleri Hatemi-J (2008) de yer verilen tablo değerleriyle karşılaştırılmıştır. } \\
\text { - } \checkmark \text { ve } X \text { işaretleri anlamlı ilişkinin sırasıyla varlığını ve yokluğunu göstermektedir. } \\
\text { - a b be ve }{ }^{\mathrm{c}} \text { sırasıyla } \% 1, \% 5 \text { ve } \% 10 \text { anlam düzeylerini temsil etmektedir. } \\
\text { - Gauss } 10 \text { programıla elde edilmiştir. }\end{array}$} \\
\hline
\end{tabular}

Değişkenlerin ve aralarındaki ilişkinin çeşitliliği, çok boyutluluğu ve yapısal kırılmalara açık olmaları, test gücünün arttırılmasına olanak sağlayan bootstrap tekniğini içeren nedensellik sorgulamalarının yapılmasını gerektirmektedir. Bu nedenle çalışmada, sosyal harcama türleriyle ekonomik büyüme arasındaki nedensellik ilişkileri Granger nedensellik testinin yanı sıra serilerin düzey halleriyle analize dâhil edildiği Toda-Yamamoto (TY) ve TodaYamamoto Bootstrap (TYb) testleriyle de sınanmaktadır. Nedensellik testlerinin sonuçları Tablo 5'te gösterilmektedir. Buna göre: GSYH ile SOCX arasında bir ilişki bulunmamaktadır. GSYH↔OLD arasında iki yönlü nedensellik ilişkisi vardır ve GSYH $\rightarrow$ OLD (Gayrisafi yurt içi hasıladan emeklilik ödemelerine doğru) nedensellik ilişkisinin Granger testine göre $\% 10$ anlam düzeyinde geçerliyken, OLD $\rightarrow$ GSYH ilişkisi Granger, TY ve TYb testlerine göre \%1 anlam düzeyinde geçerlidir. GSYH ile SUR arasında tek yönlü ve SUR $\rightarrow$ GSYH yönünde nedensellik ilişkisi mevcuttur ve bu ilişkinin $\% 1$ anlam düzeyinde geçerli olduğu kullanılan testlerce teyit edilmektedir. INC $\rightarrow \mathrm{GSYH}$ sorgulamasında nedensellik ilişkisinin Granger, TY ve TYb testlerine göre sırasıyla \% $1, \% 5$ ve $\% 5$ anlam düzeylerinde geçerli olduğu tespit edilmiştir.

Sağlık kapsamındaki harcamalarla GSYH arasındaki nedensellik ilişkilerine bakıldığında, HEA $\rightarrow$ GSYH şeklinde tek yönlü ve sadece TY testine göre \%10 anlam düzeyinde teyit edilebilen sonuçlara ulaşılmıştır. FAM ve ALP kapsamındaki sosyal harcamalar ile GSYH arasında \%10 anlam düzeyinde ve sadece Granger nedensellik ilişkisi tespit edilirken bu ilişkilerin tersinin geçerli olmadığ 1 görülmüştür. 
Sosyal Harcama Türleri ve Ekonomik Büyüme İlişkisi: Türkiye Örneği

Tablo 5. Granger, Toda-Yamamoto ve Toda-Yamamoto Bootstrap Nedensellik Testi Sonuçları

\begin{tabular}{|c|c|c|c|c|c|c|c|}
\hline \multirow[t]{2}{*}{ İlişki } & \multirow{2}{*}{$\begin{array}{c}\text { Granger } \\
\text { Ned.- (p-değ.) }\end{array}$} & \multirow{2}{*}{$\begin{array}{c}\text { Toda - } \\
\text { Yamamoto } \\
\text { Ned. (p-değ.) }\end{array}$} & \multirow{2}{*}{$\begin{array}{l}\text { MWALD } \\
\text { Test Stat. }\end{array}$} & \multicolumn{3}{|c|}{$\begin{array}{c}\text { Bootstrap Kritik } \\
\text { Değerleri }\end{array}$} & \multirow{2}{*}{$\begin{array}{l}\text { TYb } \\
\text { Ned }\end{array}$} \\
\hline & & & & $1 \%$ & $5 \%$ & $10 \%$ & \\
\hline $\mathrm{GSYH} \rightarrow \mathrm{SOCX}$ & $X(0.3496)$ & $X(0.955)$ & 0.003 & 7.873 & 4.366 & 3.051 & $x$ \\
\hline$\underline{\mathrm{SOCX} \rightarrow \mathrm{GSYH}}$ & X (0.2907) & $X(0.947)$ & 0.004 & 7.946 & 4.146 & 2.970 & $x$ \\
\hline $\mathrm{GSYH} \rightarrow \mathrm{OLD}$ & $\sqrt{ } \mathrm{c}(0.0673)$ & $X(0.296)$ & 1.092 & 7.599 & 4.203 & 2.899 & $x$ \\
\hline $\mathrm{OLD} \rightarrow \mathrm{GSYH}$ & $\sqrt{ }^{\mathrm{a}}(0.0001)$ & $\sqrt{ } \mathrm{a}(0.002)$ & 9.859 & 7.976* & 4.221 & 2.979 & $\sqrt{ } \mathrm{a}$ \\
\hline$\underline{\mathrm{GSYH}} \rightarrow \mathrm{SUR}$ & $X(0.2078)$ & $X(0.295)$ & 1.095 & 7.898 & 4.244 & 2.940 & $x$ \\
\hline$\underline{\mathrm{SUR} \rightarrow \mathrm{GSYH}}$ & $\sqrt{\mathrm{a}}(0.0088)$ & $\sqrt{ } \mathrm{a}(0.004)$ & 8.381 & 8.262* & 4.190 & 2.924 & $\sqrt{ } \mathbf{a}$ \\
\hline $\mathrm{GSYH} \rightarrow \mathrm{INC}$ & $X(0.1074)$ & $X(0.355)$ & 0.856 & 7.759 & 4.317 & 3.025 & $x$ \\
\hline $\mathrm{INC} \rightarrow \mathrm{GSYH}$ & $\sqrt{ } \mathrm{a}(0.0018)$ & $\sqrt{ }^{\mathbf{b}}(0.021)$ & 5.352 & 7.681 & $4.335 *$ & 2.983 & $\sqrt{ }^{\mathbf{b}}$ \\
\hline GSYH $\rightarrow$ HEA & $X(0.2118)$ & $X(0.710)$ & 0.138 & 8.722 & 4.577 & 3.117 & $x$ \\
\hline $\mathrm{HEA} \rightarrow \mathrm{GSYH}$ & $X(0.4721)$ & $\sqrt{ } \mathrm{c}(0.098)$ & 2.731 & 8.248 & 4.585 & 3.128 & $x$ \\
\hline $\mathrm{GSYH} \rightarrow \mathrm{FAM}$ & $X(0.1661)$ & $X(0.145)$ & 2.121 & 8.102 & 4.444 & 2.976 & $x$ \\
\hline $\mathrm{FAM} \rightarrow \mathrm{GSYH}$ & $\sqrt{ } \mathrm{c}(0.0807)$ & $X(0.260)$ & 1.267 & 8.443 & 4.320 & 2.975 & $x$ \\
\hline$\underline{\mathrm{GSYH}} \rightarrow \mathrm{ALP}$ & $X(0.2508)$ & $X(0.227)$ & 1.462 & 8.323 & 4.399 & 2.950 & $x$ \\
\hline $\mathrm{ALP} \rightarrow \mathrm{GSYH}$ & $\sqrt{ } \mathrm{c}(0.0703)$ & $X(0.225)$ & 1.471 & 7.886 & 4.437 & 3.007 & $x$ \\
\hline $\mathrm{GSYH} \rightarrow \mathrm{UNE}$ & $\sqrt{ } \mathrm{c}(0.0657)$ & $X(0.146)$ & 2.113 & 8.441 & 4.492 & 3.021 & $x$ \\
\hline$\underline{\mathrm{UNE}} \rightarrow \mathrm{GSYH}$ & $\sqrt{ } \mathrm{a}(0.0043)$ & $\sqrt{ }^{\mathbf{b}}(0.038)$ & 4.312 & 8.301 & 4.331 & $2.876 *$ & $\sqrt{ } \mathrm{c}$ \\
\hline $\mathrm{GSYH} \rightarrow \mathrm{OTH}$ & $X(0.3197)$ & $X(0.870)$ & 0.027 & 8.530 & 4.409 & 2.970 & $x$ \\
\hline $\mathrm{OTH} \rightarrow \mathrm{GSYH}$ & $X(0.4044)$ & $X(0.128)$ & 2.316 & 7.921 & 4.069 & 2.816 & $x$ \\
\hline $\begin{array}{l}\text { - * MWALD te } \\
\text { - Değgişkenler dü } \\
\text { - } \checkmark \text { ve } X \text { işaretle } \\
\text { - a, }{ }^{b} \text { ve }^{\mathrm{c}} \text { işaretler } \\
\text { - Sonuçlara Evie }\end{array}$ & $\begin{array}{l}\text { ğerinin bootstrap } \\
\text { haldedir ve VAR } \\
\text { lamlı ilişkinin sir } \\
\text { asıly } \% 1, \% 5 \text { ve } \\
\text { ve Gauss } 10 \text { pro }\end{array}$ & $\begin{array}{l}\text { tik değerlerinin } \\
\text { ikme uzunluğu } \\
\text { la varlığını ve y } \\
0 \text { anlam düzeyin } \\
\text { mlarıyla ulaşılm }\end{array}$ & $\begin{array}{l}\text { nde olduğu n } \\
\text { ike kriterine } \\
\text { uğunu göster } \\
\text { ade etmekted } \\
\text {. }\end{array}$ & $\begin{array}{l}\text { ktayı göste } \\
\text { ore seçilm } \\
\text { ektedir. }\end{array}$ & $\begin{array}{l}\text { rmektedi } \\
\text { ştir. }\end{array}$ & & \\
\hline
\end{tabular}

GSYH↔UNE arasında iki yönlü nedensellik ilişkisi mevcuttur. GSYH $\rightarrow$ UNE ilişkisi \%10 anlam düzeyinde ve sadece Granger testine göre anlamlıyken UNE $\rightarrow$ GSYH nedensellik ilişkisi Granger, TY ve TYb testlerine göre sırasıyla \%1, \%5 ve \%10 anlam düzeylerinde geçerlidir.

\section{SONUÇ}

Refah devleti yaklaşımının yerini neoliberal politikalara bırakmaya başlaması; gelir dağılımı, işsizlik, enflasyon ve istikrarsızlık gibi bir takım yapısal problemlerin ortaya çıkmasına neden olmuştur. Özellikle 1980 sonrası dönemde, küreselleşme üst söylemi altında neoliberal düşünce, uluslar üstü-arası kurumlar, çok uluslu şirketler ve teknolojik gelişmeler üzerinden hızla şekillenen kapitalist işleyişte ortaya çıkan mağdurlar, sosyal devlet ihtiyacını artmıştır. $\mathrm{Bu}$ durum sosyal harcamaların genel ekonomik işleyişteki konumu ve etkisi üzerine teorik ve pratik çalışmaları tetiklemiştir. Teorik anlamda bir tarafta ekonomiye sosyal harcamalar yoluyla müdahale edilerek, kısa dönemli sosyoekonomik sorunların giderilebileceğini iddia eden Keynesgil düşünce ve içsel büyüme modelleri yer alırken diğer tarafta müdahalelerin etkinsiz olacağını ve sadece düzey etkisiyle sınırlı kalacağını iddia eden neoliberal yaklaşım yer almıştır. Teorik açıdan yaşanan tartışmaların yanı sıra konuyla ilgili yapılan ampirik 
çalışmalar ilişkinin ülkeden ülkeye değişebildiğini ortaya koymuştur. Bu nokta, sosyal harcama türlerinin ekonomik büyüme üzerindeki etkilerinin incelenmesi ihtiyacını şekillendirmiştir.

Çalışma kapsamında elde edilen bulgulara göre; Türkiye'de 1980 sonrası yapılan toplam sosyal harcamalar ile ekonomik büyüme uzun dönemde birlikte hareket etmektedir. Bu durum, hem Gumede (2019) ve Ersin ve Baş'ın (2019) bulduğu sonuçla örtüşürken hem de sosyal harcamaların kamu harcamaları ölçeğinde ele alındığı; Şit ve Karadağ (2018), Gövdeli (2019), Ökde ve Bülbül (2019) ve Kamacı ve Kılıç (2019) ile örtüşmektedir. Detaylı bakıldığında ise eşbütünleşik ilişkinin ihtiyarlık, kazazedeler, engelliler ve sağlık kapsamında yapılan harcamalarda olduğu, diğer sosyal harcama türleri için geçerli olmadığı tespit edilmiştir. Sosyal harcama türlerinde ilişkilerin farklılaşıyor olmasının Im vd. (2011) ile Ağırman ve Yıldız (2018)'ın belirttiği gibi gelişmişlik düzeyindeki farklılıklardan kaynaklı olabileceği düşünülmektedir. Sosyal harcamalar ile ekonomik büyüme arasındaki ilişki yapısal kırılma tarihleri merkezinde incelendiğinde, 1989, 1991, 1993, 1997 ve 2004 yıllarında yapısal kırılmaların yaşandığı tespit edilmektedir. Bu tarihlerde sosyoekonomik ve politik anlamda yaşanan şokların, gelişmelerin ve yapılan düzenlemelerin detaylı incelenmesi ihtiyacı oluşmaktadır.

Nedensellik testleri sonuçlarına göre; 'toplam sosyal harcamalar' ve sosyal harcama türlerinden 'diğer sosyal politika alanları' kapsamındaki harcamalar dışında hepsinin ekonomik büyümeye neden olduğu sonucuna ulaşılmıştır. Sosyal harcamalar üst başlığında ele alındığında elde edilen bu sonuçlar, Türkiye için çalışma yapan Arısoy vd. (2010) ile Ersin ve Baş’ın (2019) ortaya koydukları sonuçlar ile örtüşmemektedir. Toplam sosyal harcamalar ile ekonomik büyüme arasında bir nedensellik ilişkisinin bulunamamış olmasına rağmen harcama türlerinde nedensellik ilişkisinin varlığının bulunmuş olması, sosyal harcamalar kapsamında uygulanan politika setinin gözden geçirilmesini işaret etmesi bakımından önemlidir. Ayrıca uzun dönemde ilişkili olan ve toplam sosyal harcamaların üçte ikisine yakınını oluşturan ihtiyarlık-emeklilik, kazazedelere-maluller ve engelliler kapsamındaki harcamaların ekonomik büyümenin yüksek anlam düzeyinde $(p<0,01)$ nedeni olması, günümüzde kamuoyunu meşgul eden erken yaşta emeklilik, sosyal güvenlik düzenlemeleri ve engellilere yönelik harcamalar gibi tartışmalar açısından kritik öneme sahiptir.

Sonuç olarak, her ne kadar Türkiye için toplam sosyal harcamalar ile ekonomik büyüme arasında nedensellik ilişkisi olmasa da detaya inilerek sosyal harcama türlerinin ekonomik büyümeye olan ilişkisi incelendiğinde bu harcamaların yatırım olarak ele alınabileceğini ifade eden içsel büyüme modelleri ve Keynesgil yaklaşımın geçerli olduğu görülmektedir. Sosyal harcamaların etkinsiz olduğu iddiasındaki neoliberal önermelerin ise sadece 'diğer sosyal politika alanları' kapsamındaki harcamalar için geçerli olduğu sonucuna ulaşılmıştır. Bu bağlamda gelişmekte olan bir ülke olan Türkiye'nin kısa-orta ve uzun dönemli ekonomik büyüme ve kalkınma planlarını yaparken ve politikalar uygularken, kaynaklarını kapsayıcı ve sürdürülebilir olarak kullanmak adına, bir taraftan sosyoekonomik açından zayıf kesimlerin desteklenmesi diğer taraftan da toplam talebin yönlendirilmesini içeren sosyal harcamalara yönelebileceği, bu şekilde hedeflerine ulaşabileceği sonucuna ulaşılmıştır. Sonraki çalışmalarda sosyal harcama türlerinin etkinliği zaman boyutlu olarak ele alınması ve ülke karşılaştırmalarına gidilmesinde yarar olduğu düşünülmektedir. 


\section{Kaynakça}

Ağırman, E. ve Yılmaz, Ö. (2018). Government Expenditures and Economic Growth: An Analysis of Developed, Developing and Underdeveloped Countries. Journal of Social Sciences of Mus Alparslan University - Anemon. 6(4). 519-529.

Alper, A. E. (2017). The Impacts of Defense, Health And Education Expenditures on Economic Growth in Turkey. Uluslararasl Ticaret ve Ekonomi Araştırmaları Dergisi. 1(2). 59-70.

Alper, F. Ö. ve Demiral, M. (2016). Public Social Expenditures and Economic Growth: Evidence from Selected OECD Countries. Research in World Economy-Sciedu Press. 7(2). 44-51.

Altıner, A. (2019). OECD Ülkelerinde Kamu Harcamaları ve Ekonomik Büyüme İlişkisi: Panel Simetrik ve Asimetrik Nedensellik Analizi. Atatürk Üniversitesi İktisadi ve İdari Bilimler Dergisi. 33(3). 849-870.

Altun, Y., İşleyen, Ş. ve Görür, Ç. (2018). Türkiye'de Eğitim ve Sağlık Harcamalarının Ekonomik Büyümeye Etkisi: 199-2017. Sosyal Bilimler Enstitüsü Dergisi. 39(223-244).

Arısoy, İ., Ünlükaplan, İ. ve Ergen, Z. (2010). Sosyal Harcamalar ve İktisadi Büyüme İlişkisi: Türkiye Ekonomisinde 1960 - 2005 Dönemine Yönelik Bir Dinamik Analiz. Maliye Dergisi. 158. 398-421.

Aydın, M. K. ve Çakmak, E. E. (2017). Sosyal Devletin Temelleri. Bilgi Sosyal Bilimler Dergisi. 34(1).1-19.

Bayat, T., Kayhan, S. ve Şentürk, M. (2012). Budget Deficits and Interest Rates: an Empirical Analysis for Turkey. Eurasian Journal of Business and Economics. 5(9). 119-128.

Baylan, M. (2015). Sosyal Güvenlik Harcamalarının Makroekonomik Etkileri: Bir Literatür Taraması. KSÜ Sosyal Bilimler Dergisi. 12(1). 29-52.

Bloom, D. E., Canning, D. and Fink, G. (2010). Implications of Population Ageing for Economic Growth. Oxford Review of Economic Policy The Economics of Ageing. 26(4). 583-612.

Chang, H. J. (2002). Kicking Away the Ladder: Development Strategy in Historical Perspective. Anthem Press. New York.
Çalışkan, Ş., Karabacak, M. ve Meçik, O. (2017). Türkiye Ekonomisinde Eğitim Harcamaları ve Ekonomik Büyüme İlişkisi: Bootstrap Toda-Yamamoto Nedensellik Testi Yaklaşımı. Kocaeli Üniversitesi Sosyal Bilimler Dergisi. 33. 45-56.

Destebaşı, E. (2017). Savunma, Eğitim ve Sağlik Harcamaları Arasındaki Nedensellik Analizi: D8 Ülkeleri Örneği. Enderun Dergisi. 1(1). 28-43.

Diler, H. G. (2016). Kamu Harcamalar1Ekonomik Büyüme: Türkiye Üzerinde Bir Uygulama. Iktisat Politikası Araştırmaları Dergisi. 3(1). 21-36.

Duman, Y. K. (2017). Türkiye'de Cari İşlemler Dengesi ve Ekonomik Büyüme Arasındaki İlişki. Sakarya İktisat Dergisi. 6(4). 12-28.

Ebeling, Derek James. The Effects of Social Spending on Economic Growth and Standards of Living Within U.S. States (2016). University of North Dakota, Theses and Dissertations. 1891. [https://commons.und.edu/theses/1891].

Efron, B. (1979). Bootstrap Methods: Another Look at the Jackknife. The Annals of Statistics. 7(1). 1-26.

Elekdağ, S. (2012). Social Spending in Korea: Can it Foster Sustainable and Inclusive Growth? IMF Working Paper. WP/12/250:1-22.

Ersin, İ. ve Baş, H. (2019). Güney Avrupa Refah Ülkelerinde Sosyal Harcamalar ve Ekonomik Büyüme Arasındaki İlişkinin İncelenmesi. Sosyal Güvenlik Dergisi. 9(1). 193-213.

Furceri, D. and Zdzienicka, A. (2012). The Effects of Social Spending on Economic Activity: Empirical Evidence from a Panel of OECD Countries. Fiscal Studies. 33(1). 129152.

Gioacchino, D. and Sabani, L. (2009). The Politics of Social Protection: Social Expenditure vs Market Regulation. International Review of Applied Economics. 23(3). 387-404.

Gölpek, F., Köse, Z. ve Doğan, F. C. (2019). Savunma Harcamalarının Ekonomik Büyüme Üzerindeki Etkisinin İncelenmesi: Türkiye Örneği. Uluslararast Ticaret ve Ekonomi Araştırmaları Dergisi. 3(1). 30-40. 
Gövdeli, T. (2019). Kamu Harcamaları ve Ekonomik Büyüme: Türkiye'de Wagner Yasas1 ve Keynesyen Hipotezin Ampirik Analizi. Atatürk Üniversitesi İktisadi ve İdari Bilimler Dergisi. 33(3). 995-1010.

Granger, C. W. J. (1969). Investigating Causal Relations by Econometric Models and CrossSpectral Methods. Econometrica. 37(3). 424438.

Gregory, A. W. and Hansen, B. E. (1996). Residual-Based Tests for Cointegration in Models With Regime Shifts. Journal of Econometrics. 70(1). 99-126.

Gumede, R. T. (2019). The Nexus Between Social Spending and Economic Growth in South Africa: A Cointegration Approach. A Dissertation-Degree of Masters (MCom) in Economics. University of Zululand. KwaDlangezwa.

Gümüş, İ. (2018). Tarihsel Perspektifte Refah Devleti: Doğuş, Yükseliş ve Yeniden Yapılanma Süreci. Journal of Political Administrative and Local Studies. 1(1). 33-66.

Gweke, J. Richard M. \& Warrant D. (1983). Comparing Alternative Tests of Causality in Temporal Systems. Journal of Econometrics. 21(2).

Hacker, S. ve Hatemi-J, A. (2005). A Test for Multivariate ARCH Effects. Applied Economics Letters. 12(7). 411-417.

Hacker, S. ve Hatemi-J, A. (2006). Tests for Causality Between Integrated Variables Based on Asymptotic and Bootstrap Distributions: Theory and Application. Applied Economics. 38(13). 1489-1500.

Hassan, A. and Hisham, M. (2014). An Econometric Perspective Social Spending and Economic Growth in the Sudan. [http://dx.doi.org/10.2139/ssrn.2433463] (Erişim: 15 Mayıs 2019).

Hatemi-J, A. (2005). Bootstrap-Corrected Tests for Causality: Theory and Applications in Finance. Invited Key-Speaker Presentation at II Simposio Nacional de Docentes En Finanzas. 1315. Bogota.

Hatemi-J, A. (2008). Tests for Cointegration with Two Unknown Regime Shifts with an Application to Financial Market Integration. Empirical Economics. 35(3). 497-505.
Im, T., Cho, W. and Porumbescu, G. (2011). An Empirical Analysis of the Relation Between Social Spending and Economic Growth in Developing Countries and OECD Members. Asia Pacific Journal of Public Administration. 33(1). 37-55.

İğdeli, A. (2019). Ar-Ge ve Eğitim Harcamalarının Ekonomik Büyüme Üzerindeki Etkisi: Türkiye Örneği. MANAS Sosyal Araştırmalar Dergisi. 8(3). 2517-2538.

Johnny, N., Dumani, M. ve Timipere, E. T. (2018). Effect of Government Social Expenditure on Economic Growth in Nigeria (1981-2016). International Journal of Innovative Research and Advanced Studies (IJIRAS). 5(1). 265-277.

Kamacı, A. ve Kılıç, H. (2019). Kamu Harcamalarının Ekonomik Büyüme ve İşsizlik Üzerindeki Etkisi: OECD Ülkeleri Örneği. Politik Ekonomik Kuram. 3(1). 113-128.

Karış, Ç. (2019). Eğitim Harcamaları ve Ekonomik Büyüme Üzerine Bir Nedensellik Analizi: Türkiye Örneği. Bingöl Üniversitesi Sosyal Bilimler Enstitüsü Dergisi. 9(18). 10671088.

Kayhan, S., Bayat, T. ve Yüzbaş1, B. (2013). Government Expenditures and Trade Deficits in Turkey: Time Domain and Frequency Domain Analyses. Economic Modelling. 35(c). 153-158.

Khan, H. ve Bashar, O. K. M. R. (2015). Social Expenditure and Economic Growth: Evidence From Australia and New Zealand Using Cointegration and Causality Tests. The Journal of Developing Areas. 49(4). 285-300.

Lindert, P. (1996). Does Social Spending Deter Economic Growth? Challenge. 39(3). 17-23.

MacKinnon, J. G. (1996). Numerical Distribution Functions for Unit Root and Cointegration Tests. Journal of Applied Econometrics. 11. 601-618.

Maestas, N., Mullen, K. J. ve Powell, D. (2016). The Effect of Population Aging on Economic Growth, The Labor Force and Productivity. RAND Labor \& Population-WR-1063.

Malyovanyi, M., Ivanova, N., Melnyk, K., Nepochatenko, O. ve Rolinskyi, O. (2018). Assessment of the Social Expenditure İmpact on the Economic Growth in OECD Countries. Problems and Perspectives in Management. 16(3). 389-405. 
Sosyal Harcama Türleri ve Ekonomik Büyüme İlişkisi: Türkiye Örneği

Michel, S. (2018). Social Spending as a Driver of Economic Growth: Has the Theoretical Consensus of the 1980s Led to Successful Economic Policies? in Macroeconomic Theory and the Eurozone Crisis, Ed: Alcouffe Alain; Baslé Maurice and Poettinger Monika. Routledge Studies in the History of Economics, Routledge.

Minoru, W., Miyake Y. and Masaya, Y. (2018). Unemployment, Income Growth and Social Security. MPRA Paper No. 86155

Nagarajan, N. R., Teixeira, A. A. C. and Silva, S. T. (2016). The Impact of An Ageing Population on Economic Growth: An Exploratory Review of the Main Mechanisms. Análise Social. 218(1). 4-35.

Ökde, B. ve Bülbül, D. (2019). Kamu Harcamaları ve Ekonomik Büyüme Arasındaki İlişki: G7 Ülkeleri İçin Panel Veri Analizi. Elektronik Sosyal Bilimler Dergisi - Esosder. 18(69). 308-317.

Reimat, A. (2012). Old Age Pensions, Demography and Economic Growth in the Long Run: The French Case Revisited. Historical Social Research / Historische Sozialforschung. 37(4-142). 327-347.

Reis, Anderson Gedeon Buzar ve Bueno, Newton Paulo. (2019). The Effect of Public Social Spending on the Economic Growth: A Comparative Analysis Between ECLAC and OECD Member Countries. Revista Gestao \& Tecnologia. 19(1). 73-89.

Rubin, Jennifer, Jirka Taylor, Joachim Krapels, Alex Sutherland, Melissa Felician, Jodi L. Liu, Lois M. Davis, and Charlene Rohr. Are Better Health Outcomes Related to Social Expenditure? A Cross-National Empirical Analysis of Social Expenditure and Population Health Measures. Santa Monica, CA: RAND Corporation. 2016. [https://www.rand.org/pubs/research_reports/R R1252.html].

Say1l, H., Mengenci, C. ve Bürcü, R. (2015). Yönetim Düşüncesinin Evrimi ve Sosyal Hizmet Yaklaşımı. SDÜ Vizyoner Dergisi. Sosyal Hizmet Özel Sayısı.

Sims, C. A. (1972). Money, Income and Causality. The American Economic Review. 62(4). 540-552.
Şeker, A. (2012). Sosyal Hizmete Giriş. T.C. Anadolu Üniversitesi Yayını. No: 2533. Açıöğretim Fakültesi Yayını. No: 1504. Eskişehir.

Şeker, M. (2011). Yerel Yönetimlerde Sosyal Bütçeyi İzleme Raporu. TESEV Yayınları. İstanbul.

Şit, M. ve Karadağ, H. (2018). Türkiye Ekonomisinde Kamu Harcamalar1-Ekonomik Büyüme İlişkisi: Toda-Yamamoto Nedensellik Testi. Uluslararast Ticaret ve Ekonomi Araştırmaları Dergisi. 2(1). 33-41.

Takım, A. (2010). Türkiye'de Ekonomik Büyüme ile İşsizlik Arasındaki İlişsi: Granger Nedensellik Testi. Dumlupınar Üniversitesi Sosyal Bilimler Dergisi. 27. 1-8.

Taşar, İ. (2015). İ̧̧sel Büyüme Modelleri Çerçevesinde Türkiye'de Ekonomik Büyümenin Yapısal Dönüşümü. İnönü Üniversitesi Sosyal Bilimler Enstitüsü İktisat Anabilim Dalı İktisat Programı Yayınlanmamış Doktora Tezi. Danışman: Doç. Dr. Tayfur Bayat, Malatya.

Toda, H. Y. and Yamamoto, T. (1995). Statistical Inferences in Vector Autoregressions with Possibly Integrated Processes. Journal of Econometrics. 66. 225-250.

Yağtu, G. ve Sezgin, Ş. (2019). Türkiye'de Savunma Harcamalarının Ekonomik Büyüme İlişkisi. Avrasya Sosyal ve Ekonomi Araştırmaları Dergisi. 6(8). 1-13.

Y1lanc1, V. ve Öztürk, Z. A. (2010). Türkiye ile En Büyük Beş Ticaret Ortağının Hisse Senedi Piyasaları Arasındaki Entegrasyon İlişkisinin Analizi: Yapısal Kırılmalı Birim Kök ve Eşbütünleşme Analizi. Erciyes Üniversitesi IIIBF Dergisi. 36. 261-279.

Yılgör, M., Karahan, Ö. ve Topdağ, D. (2018). Türkiye'de Kamu Harcamalarının Ekonomik Büyüme Üzerine Etkisi. Yönetim ve Ekonomi Araştırmaları Dergisi. 16(4). 256-271. 
